\title{
Middle Jurassic record of the limnic ostracode genus Rosacythere (Limnocytheridae, Timiriaseviinae): implications on the origin and evolution of the Kovalevskiella group
}

\author{
J.-P. COLIN' \& P. CARBONEL ${ }^{2}$ \\ 'Esso Rep, 213 Cours Victor Hugo, 33323 Bègles Cedex, France. \\ ¿Département de Géologie et Océanographie, Université de Bordeaux, Avenue des Facultés, 33405 Talence Cedex, France.
}

\begin{abstract}
Two species of the limnic ostracode genus Rosacythere Colin (Limnocytheridae, Timiriaseviinae) have been identified in the uppermost Bajocian (Middle Jurassic) of the southern part of the Paris Basin, France. This record is the earliest for this genus and for the Kovalevskiella group' of Colin \& Danielopol $(1978 ; 1980)$. This study also confirms that most of the Timiriaseviinae morphological groups really started to diversify during the Middle Jurassic. J. Micropalaeontol. 15(2): 187-191, October 1996.
\end{abstract}

\section{INTRODUCTION}

The limnic ostracod genus Rosacythere, defined by Colin (in Colin \& Danielopol, 1980), belongs to the family Limnocytheridae, subfamily Timiriaseviinae. It is one of the genera forming the 'Kovaleuskiella group' defined by Colin \& Danielopol $(1978,1980)$.

According to the authors, the main diagnostic characters of this lineage are: small-sized carapace, about $0.5 \mathrm{~mm}$ (or less): ornamentation in 'rosettes' or micropustulose, 'raspberry-type' (Colin, 1991); inverse hingement with positive elements on the left valve; right valve < left valve: no, or one to two vertical sulci: marked sexual dimorphism, females having a developed brood pouch.

The 'raspberry-type' of ornamentation is in fact derived from the 'rosettes'-type by the development of a small hemispherical pustule at the intersection of the alveolae muri. These types of ornamentation which are always present in the genus Kovaleuskiella are sometimes absent in some species of Rosacythere (Theriosynoecum? sp. 4 and Theriosynoecum? sp. 2 Andreu, 1978 from the uppermost Albian-Cenomanian of northern Spain) and Frambocythere (Frambocythere cf. tumiensis ferreri Colin in Babinot, 1980 from the Maastrichtian of SE France) which are totally smooth.

Until recently, the earliest known representatives of this lineage which comprises the genera Rosacythere Colin, 1980, Frambocythere Colin, 1980, Kovaleuskiella Klein, 1963, and probably Abrotocythere Zhao, 1987, were not older than Early Cretaceous as indicated by the presence of 'Timiriasevia' cardiiformis Rosenfeld \& Raab, 1984 in the 'Neocomian' of Israel. Zhao (1987) considered the genus Abrotocythere as a 'Tertiary derivative' of Rosacythere, which differs from other genera of the Kovalevskiella lineage by its normal hinge with positive elements on the right valve (left valve $>$ right valve) and its less regular type of ornamentation.

The genus Rosacythere was considered to be restricted to the Late Aptian to Cenomanian interval (Fig. 1) of southern Europe, being known especially from SW France, Spain, Portugal and Hungary (Colin, 1974; Colin \& Danielopol, 1980: Andreu, 1978, 1983; Cabral, 1995; Zalanyi, 1959) (Fig. 2). The genus Frambocythere, originally thought to be restricted to the Late Maastrichtian to Early Eocene interval from southern Europe (southern Belgium, France and Spain), India and China, has recently been identified in the Albian of Zaire (Colin, 1993). The oldest known species of Kovalevskiella dates from the Oligocene of Germany (Carbonnel \& Ritzkowski, 1969), and in the present day this genus is confined to the hypogean and interstitial realms in south-central Europe (Colin \& Danielopol, 1980; Carbonel et al., 1986). The genus Abrotocythere has until now been only found in the Miocene (or possibly Oligocene) of SW China (Zhao, 1987).

Although non-marine sediments were widespread during the Late Jurassic and the Early Cretaceous ('PurbeckoWealden' facies) in many parts of the world, no representative of this group, other than the 'Neocomian' Israeli record of 'Timiriasevia' cardiiformis (Rosenfeld \& Raab, 1984), has been reported from this period, whereas other Timiriaseviinae such as Timiriasevia and Theriosynoecum ( $=$ Bisulcocypris Pinto \& Sanguinetti, 1958 and Dryelba Sohn, 1982, auct.) were common.

\section{THE GENUS ROSACYTHERE IN THE MIDDLE JURASSIC}

Although it is currently accepted that the first Timiriaseviinae probably appeared during the Triassic (Colin \& Danielopol, 1980), they really started to develop and to diversify only during the Middle Jurassic and especially during the Bathonian as indicated by the presence of numerous species of the genera Timiriasevia Mandelstam, 1947, and Theriosynoecum Branson, 1936 (Whatley, 1990; Colin, in press). Until now, representatives of the Kovalevskiella Group were not known from this period, although few species showed strong affinities with it.

In the Late Bathonian of SW France, Rohr (1976) described a small species $(L=0.45-0.53 \mathrm{~mm})$ of Timiraseviinae, 'Bisulcocypris' pusilla (also reported and illustrated as Theriosynoecum sp. by Malz et al. (1985) in the Early Bathonian of Sardinia and as Metacypris sp. 2 by Mette (1995) in the Callovian of southern Tunisia) showing strong morphological affinities with the Kovalevskiella Group, but from which it differs mainly by its weak reticulate ornamentation. 


\begin{tabular}{|c|c|c|c|c|c|c|c|c|c|c|}
\hline AGE & 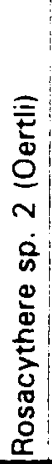 & 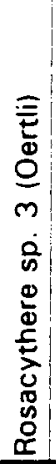 & 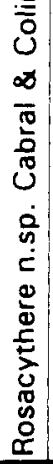 & 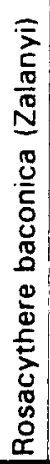 & 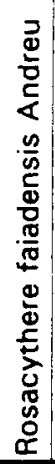 & 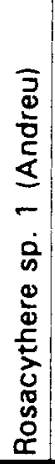 & 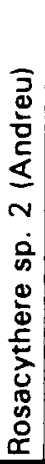 & 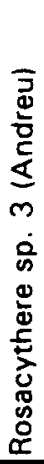 & 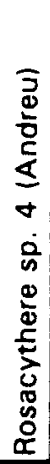 & 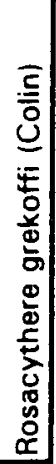 \\
\hline Cenomanian & & & & & & & & & & \\
\hline Albian & & & & I. & & & & & & \\
\hline Aptian & & & $\tau$ & & & & & & & \\
\hline Barremian & & & & & & & & & & \\
\hline Hauterivian & & & & & & & & & & \\
\hline Valanginian & & & & & & & & & & \\
\hline Berriasian & & & & & & & & & & \\
\hline Portlandian & & & & & & & & & & \\
\hline Kimmeridgian & & & & & & & & & & \\
\hline Oxfordian & & & & & & & & & & \\
\hline Callovian & & & & & & & & & & \\
\hline Bathonian & & & & & & & & & & \\
\hline Bajocian & & 1 & & & & & & & & \\
\hline
\end{tabular}

Fig. 1. Stratigraphical distribution of Rosacythere species.

'Bisulcocypris' calcar Grékoff, 1963, from the Bathonian of the Majunga Basin in Madagascar has a morphology and a micro-pustulose ornamentation very close to the
Kovalevskiella Group and, because of the presence of two sulci, especially to the genus Frambocythere. It differs essentially by its large size $(\mathrm{L}=0.70-0.94 \mathrm{~mm})$ which make it probably related to to the Theriosynoecum Group.

A re-examination of uppermost Bajocian material (Mourier, unpublished) from the southern part of the Paris Basin (Vienne valley, about $35 \mathrm{~km} \mathrm{SE}$ of Poitiers), previously studied and illustrated by Oertli (in Bernard et al., 1957 and Oertli, 1963), and Dépêche (1984) allowed us to attribute to the genus Rosacythere two forms originally tentatively assigned to the genus Gomphocythere Sars, 1924. Pinto \& Sanguinetti (1962) recognized that these two species belonged to a new indeterminate genus and Dépêche (1984) attributed one of this species to the genus Kovalevskiella and the other to the genus Rosacythere. The two species encountered possess all the diagnostic features of the genus Rosacythere: size, ornamentation, inverse hingement, sexual dimorphism. In the type-locality (La Tour-au-Cognum, near the town of Civaux, Vienne valley ; IGN map 1/25000 Chauvigny 8 ) they have been found in a thin shaly interval rich in organic matter, $2 \mathrm{~m}$ below a limestone level having yielded the uppermost Bajocian ammonite Parkinsonia aff. subtilis Arkell. In the studied horizon Rosacythere species are associated with Cypridea? postelongata Oertli, Timiriasevia sp. (=Gomphocythere nov. sp. 1 Oertli), Erpetocypris? sp. and charophyte gyrogonites.

\section{COMMENTS ON THE ORIGIN AND EVOLUTION OF THE KOVALESKIELLA GROUP}

This study shows that the oldest known representatives of the Kovalevskiella lineage already possessed most of the diagnostic characters of the group: size, ornamentation, sexual dimorphism, inverse hinge.

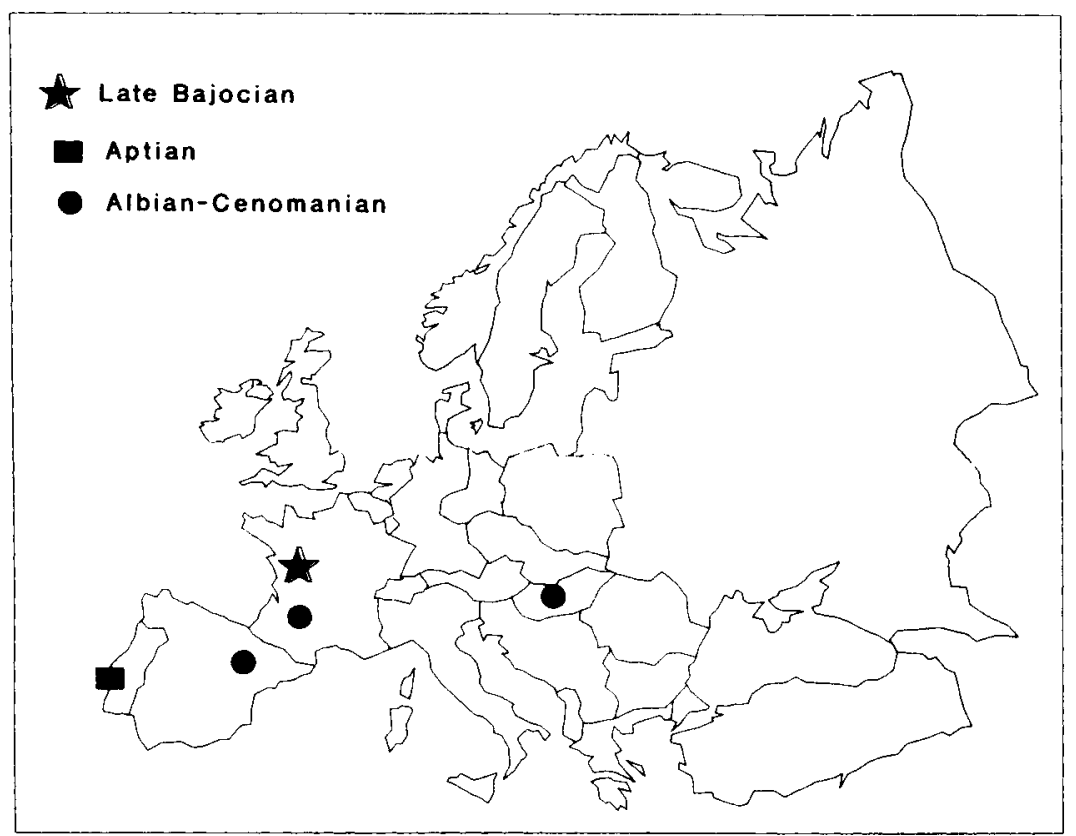

Fig. 2. Geographical distribution of Rosacythere species. Late Bajocian: Bernard et al., (1957) and this paper: Aptian: Cabral (1995), Cabral \& Colin (in prep.); Albian: Zalanyi (1959), Andreu (1978, 1983); Cenomanian: Colin (1974), Colin \& Danielopol (1980). 
A close observation shows that the Kovalevskiella ornamentation, i.e. 'raspberry-type', which was generally developed by the end of the Cretaceous (in the genus Frambocythere) and later in the Cenozoic (in the genus Kovalevskiella), was derived from the 'rosettes'-type by the development of a small hemispherical pustule at the intersection of the alveolae muri. It is therefore suggested that the 'rosettes'-type is a more primitive character.

It is also suggested that the absence of sulcus is a primitive character. Bisulcate forms make their first appearance in the Albian with the genus Frambocythere. Monosulcate forms, appearing in the Oligocene with the genus Kovalevskiella would therefore be more evolved. The fact that one of the youngest known species of Frambocythere ( $F$. valeroni Tambareau) from the Early Eocene of southern France (Tambareau et al., 1991) shows a tendency toward a single sulcus would support this hypothesis.

\section{TAXONOMIC NOTES}

Illustrated specimens are deposited in the Collections of the University of Geneva, Geneva, Switzerland.

Due to the scarcity of the material and especially of adult specimens both species are left in open nomenclature.

Subclass Ostracoda Latreille, 1806

Order Podocopida G.W. Müller, 1894

Suborder Podocopina Sars, 1866

Superfamily Cytheracea Baird, 1850

Family Limnocytheridae Sars, 1925

Subfamily Timiriaseviinae Mandelstam 1960 (emend. Colin \& Danielopol, 1978)

Genus Rosacythere Colin, 1980

Type species (by original designation): Theriosynoecum grekoffi Colin, 1974.

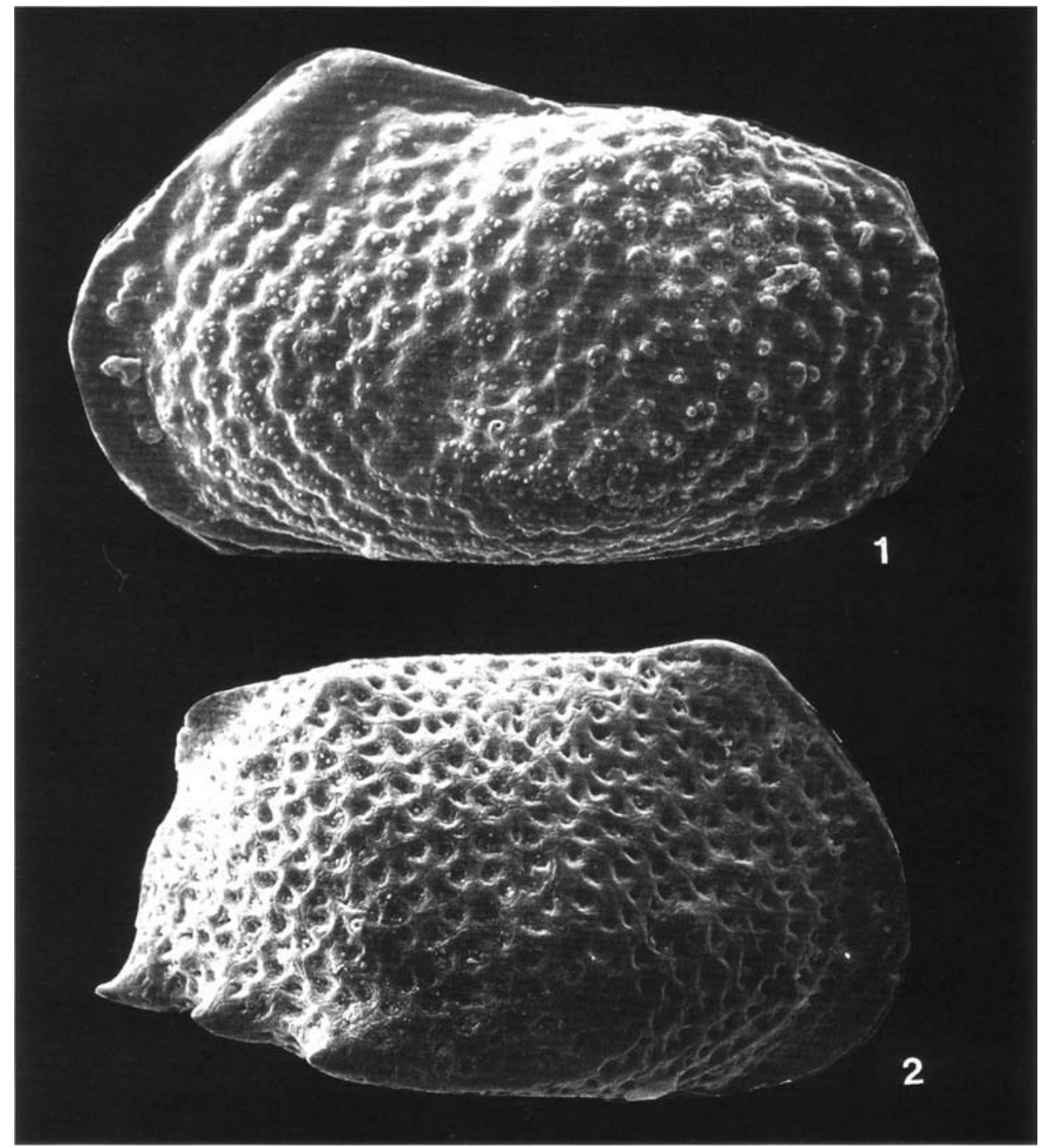

Fig. 3. 1. Rosacythere sp. 2 (Oertli, 1957), left valve, lateral view, $\times 200$. 2. Rosacythere sp. 3 (Oertli, 1957), right valve, lateral view, $\times 200$. Vienne valiey, level BE 195 of Bernard et al. 1957. Uppermost Bajocian. 
Diagnosis (translated from Colin \& Danielopol, 1980). Timiriaseviinae with small-sized carapace (about $0.5 \mathrm{~mm}$ ), ornamented by triangular alveolae disposed in 'rosettes'. Hinge lophodont, inverse, with terminal positive elements on the left valve. Presence of a brood pouch in females.

This diagnosis is emended to include species having a micropustulose, 'raspberry'-type of ornamentation, and the smooth species of Rosacythere found by Andreu (1978) in the Late Albian of northern Spain.

\section{Rosacythere sp. 2 (Oertli, 1957)}

(Fig. 3, 1)

1957 Gomphocythere? nov. sp. 2 Oertli; Bernard et al.: 764, pl. 23, figs 1-4.

1962 Genus incertus n.sp. 2 (Oertli); Pinto \& Sanguinetti: 23, 31.

1963 Gomphocythere ? Oertli, pl. 27-2.

1984 Kovaleuskiella 'nov. sp. 2' (Oertli); Dépêche: 210, pl. 5, fig. 3 .

1985 Kovalevskiella sp. Dépêche, tabl. 6: 122.

Remarks. This species differs from all other described species of Rosacythere by its 'raspberry'-type of ornamentation similar to the genera Kovalevskiella and Frambocythere. Such an ornamentation in the genus Rosacythere has been observed in a new species from the Late Aptian of Portugal (Cabral, 1995 and Cabral \& Colin in prep.). On adult specimens, pustules are often papillate. Juvenile specimens show a spine at the postero-dorsal and postero-ventral angles (Oertli in Bernard et al., 1957, pl. 13, fig. 2). The right valve is the largest (inverse). Hinge with positive elements on the left valve. Narrow anterior marginal zone (1/12 on the length) with about 10 simple pore canals (fide Oertli in Bernard et al., 1957).

Dimensions. $\mathrm{L}=0.300-0.550 \mathrm{~mm}$. $\mathrm{H}=0.190-0.305 \mathrm{~mm}$.

Rosacythere sp. 3 (Oertli, 1957)

(Fig. 3, 2)

1957 Gomphocythere? nov. sp. 3 Oertli; Bernard et al:: 764 , pl. 23, figs 5-14.

1962 Genus incertus. n.sp. 3 (Oertli); Pinto \& Sanguinetti: 23,31

1963 Gomphocythere ? Oertli, pl. 27-2.

1984 Rosacythere 'nov. sp. 3' (Oertli); Dépêche: 210-211, pl. 5 , fig. 4.

1985 Rosacythere sp. Dépêche, tabl. 6: 122.

Remarks. This species possess the characteristic 'rosette' ornamentation of Rosacythere, and. differs from other known species of this genus essentially by the presence of three well developed conical spines on the posterior half of the ventral margin. It possesses a conical spine on the dorsal margin anterior to the posterodorsal angle. That is characteristic of the type-species Rosacythere grekoffi (Colin, 1974) from the Cenomanian of Dordogne (SW France). The juvenile specimen illustrated by Dépêche (pl. 5 , fig. 4) shows another conical spine located in the middle part of the valves. The right valve is the largest (inverse). Hinge with positive elements on the left valve (Oertli in Bernard et al., 1957, pl. 23, fig. 13)

Dimensions. $\mathrm{L}=0.350-0.580 \mathrm{~mm}$. $\mathrm{H}=0.180-0.275 \mathrm{~mm}$.

\section{CONCLUSIONS}

The identification of two species of the limnic ostracod genus Rosacythere (Limnocytheridae, Timiriaseviinae) in the uppermost Bajocian of France is the earliest record of representatives of the 'Kovalevskiella group' of Colin \& Danielopol (1980) which will have two periods of maximum development during the Late Maastrichtian-Early Eocene with the genus Frambocythere and Oligocene-Recent with the genus Kovalsvekiella.

This discovery also confirms that most of the Timiriaseviinae morphological groups (Timiriasevia-Metacypris, Theriosynoecum, Kovaleuskiella) which appeared during the Triassic, really started their diversification during the Middle Jurassic.

\section{ACKNOWLEDGEMENTS}

We are glad to express our sincere thanks to Dr. H.J. Oertli (Pau, France) for the loan of the specimens, Dr D. L. Danielopol (Mondsee, Austria) for his critical and constructive review of this work and all the participants to the Working Group 'Evolution des Timiriaseviinae' with especially Dr Y. Tambareau (Toulouse) and Dr J.-F. Babinot (Marseille) for fruitful discussions and exchanges of material and ideas.

\section{Manuscript received March 1995 Manuscript accepted May 1996}

\section{REFERENCES}

Andreu, B. 1978. Ostracodes albiens et cénomaniens dans la zone sud-pyrénéenne, les Chaînes Ibériques Aragonaises, le Portugal. Travaux du Laboratoire de Géologie de l'Université Paul Sabatier, Toulouse: 1-290.

Andreu, B. 1983. Nouvelles espèces d'ostracodes de l'Albien et du Cénomanien Sud-Pyrénéen (Sierra d'Aulet, Espagne). Bulletin des Centres de Recherche Exploration-Production Elf-Aquitaine, Pau, 7: 1-43.

Babinot, J.-F. 1980. Les ostracodes du Crétacé supérieur de Provence. Systématique-Biostratigraphie-PaléoécologiePaleogéographie. Travaux du Laboratoire de Géologie Historique et de Paléontologie, Université de Provence, Marseille, 10: $1-634$.

Bernard, F., Bizon, J.-J. \& Oertli, H. J., 1957. Ostracodes lacustres du Bathonien du Poitou (Bassin de Paris). Bulletin de la Société géologique de France, Paris, 6: 753-770.

Cabral, M. C. 1995. Ostracodos do Cretácico inferior do Algarve c da região de Lisboa: Sistemática, bioestratigrafia, aspectos palcoecológicos e paleobiogeográficos. Departamento de Geologia da Faculdade de Ciencias de Lisboa: 1-442.

Carbonel, P., Colin, J.-P., Danielopol, D. L. \& Londeix, L. 1986. Kovalevskiella (Ostracoda, Timiriaseviinae), genre à mode de vie benthique depuis l'Oligocène, son adaptation à la vie interstitielle. Géobios, Lyon, 19: 677-687.

Carbonnel, G. \& Ritzkowski, S. 1969. Ostracodes lacustres de l'Oligocène de la Hesse (Allemagne). Archives des Sciences (Genève), 22: 55-82.

Colin, J.-P. 1974. Nouvelles espèces des genres Metacypris et Theriosynoecum (ostracodes lacustres) dans le Cénomanien de Dordogne (S.O.) France. Revista española de Micropaleontologia, Madrid, 6: 183-189.

Colin, J.-P. 1991. On Frambocythere tumiensis (Helmdach) ferreri Colin. Stereo-Atlas of Ostracod Shells, London, 18: 37-40. 
Colin, J.-P. 1993. An early representative of the genus Frambocythere Colin, 1980: Frambocythere pustulosa (Grékoff, 1957) from the Altian of Zaire. Journal of Micropalaeontology, London, 12: 170.

Colin. J.-P. in press. Les ostracodes limniques du Jurassique européen: utilisation stratigraphique. Bulletin des Centres de Recherche Exploration-Production Elf Aquitaine, Pau.

Colin. J.-P. \& Danielopol, D. L. 1978. New data on the systematics of the Limnocytheridae (Ostracoda, Crustacea). Géobios, Lyon, 11: $563-567$.

Colin J.-P. \& Danielopol D.L. 1980. Sur la morphologie, la systématique, la biogéographie et l'évolution des ostracodes Timiriaseviinae (Limnocytheridae). Paléobiologie continentale, Montpellier, 11: 1-51.

Dépêche, F. 1984. Les ostracodes d'une plate-forme continentale au Jurassique: recherches sur le Bathonien du Bassin Parisien. Mémoire des Sciences de la Terre, Université Pierre et Marie Curie, Paris, 84 20: $1-149$

Dépêche, F, 1985. Lias supérieur, Dogger, Malm. In Oertli, H.J. (Ed.), Atlas des Ostracodes de France. Bulletin des Centres de Recherche Exploration-Production Elf-Aquitaine, Mémoire, Pau, 9: $119-145$.

Grékoff, N. 1963. Contribution à létude des ostracodes du Mésozoïque moyen (Bathonien-Valanginien) du Bassin de Majunga, Madgascar. Revue de l'Institut français du Pétrole, 18: $1709-1783$.

Malz., H., Holmann, K. \& Radtke, G. 1985. Biostratigraphy of the Middle Jurassic of N.W. Sardinia by means of ostracods. Senckenbergiana lethaea. Frankfurt am Main, 66: 299-345.
Mette, W. 1995. Ostracods from the middle Jurassic of southern Tunisia. Beringeria, 16: 259-348.

Oertli, H.J. 1963. Faunes d'ostracodes du Mésozoüque de France, 1-57. E.J. Brill, Leiden.

Pinto, I.D. \& Sanguinetti, Y.T. 1962. A complete revision of the genera Bisulcocypris and Theriosynoecum (Ostracoda) with the world geographical and stratigraphical distribution (including Metacypris, Elpidium, Gomphocythere and Cytheridella). Publicaçao especial. Escola de Geologia, Universidad do Rio Grande do Sul, 4: 1-165.

Rohr. W.M. 1976. Mitteljurassische Ostracoden aus den Grands Causses Süd-Frankreichs. Inaugural Dissertation Freien Universität Berlin, 1-164.

Rosenfeld A. \& Raab M. 1984. Lower Cretaceous ostracodes from Israel and Sinaï. Geological Survey of Israel special Publication, Jerusalem, 4: 85-134.

Tambareau, Y., Gruas-Cavagnetlo, C.. Feist, M. \& Villatte, J. 1991. Flores et faunes continentales ilerdiennes du versant sud de la Montagne Noire et de la Montagne d'Alaric. Revue de Micropaléontologie, 34: 69-90.

Whatley, R. 1990. The relationship between extrinsic and intrinsic events in the evolution of Mesozoic non-marine Ostracoda. In Kaufmann, E.G. \& Walliser, O.M. (Eds), Extinction Events in Earth History. Springer-Verlag, Berlin, 253-263.

Zalanyi, B. 1959. Ostracoden-Faunen aus der Apt-stufe des nördlichen Bakonygebirges. Jahrbuch der ungarischen geologischen Anstalt, 47: 357-565.

Zhao Yuhong, 1987. On Abrotocythere quinquecornis Zhao gen. et sp. nov. Stereo-Atlas of Ostracod Shells, London, 14: 111-114. 